Chemical Activities of Fungi

By Prof. Jackson W. Foster. Pp. xviii +648. (New York : Academic Press, Inc. ; London : H. K. Lewis and Co., Ltd., 1949.) 9.50 dollars.

THE author of this book, who is professor of bacteriology in the University of Texas, defines its purpose as "to stress the subject matter from the standpoint of dynamics, that is, transformations [author's italics] effected by fungi". He states that it is designed primarily for the beginning student "with an eye toward the use of this book as a text for college courses at the upper-class or graduate level". $\mathrm{He}$ excuses his admitted omission of large and important aspects of the chemical activities of fungi by saying "it was done advisedly to keep the size of the book within bounds".

The nineteen chapters of the book contain the following headings: I, introduction, history, perspective ; 2, the methodology of mould metabolism ; 3 , chemical nature of the mould mycelium ; 4, general considerations of mould metabolism; 5, natural variations ; 6, mutations, physiological genetics, and biochemical syntheses; 7 , trace element nutrition of fungi ; 8, lactic acid formation by fungi ; 9, alcoholic fermentation by moulds ; 10 , oxalic acid metabolism ; 11, fumaric and other $\mathrm{C}_{4}$-dicarboxylic acids; 12 , citric acid; 13, itaconic acid; 14, kojic acid; 15 , gluconic and other sugar acids; 16, carbohydrates produced by fungi ; .17, nitrogen metabolism of fungi ; 18, other transformations in fungi; 19, microbiological aspects of penicillin. The title of the book is inaccurate, misleading and too comprehensive. Little reference is made to modern work on mould metabolic products which have been described during the past twenty years and many of which have pronounced antibiotic properties. Most attention is paid, as will be clear from the contents, to the numerous theories, often mutually contradictory, of the mechanism of formation of a small number of old-established mould metabolic products. Further, there is little reference to any of the higher fungi, the subject-matter being confined almost exclusively to moulds.

\section{Deserts on the March}

By Paul B. Sears. Pp. xi+181. (London : Routledge and Kegan Paul, Ltd., 1949.) 10s. 6d. net.

LL but the last chapter of this book was written and printed in 1935, in the dark days in the United States after the 'famine years' of 1933 and 1934 had directed the urgent attention of the whole nation to the dangers of soil erosion. Later the problem was pushed into the background by the urgency of the War; now once again it is being appreciated as one of the great problems of human survival. Dr. P. B. Sears is professor of botany at Oberlin, Ohio, and he presents the picture with a greater scientific accuracy, a more pleasantly moving narrative and avoidance of the dangerous sensationalism of other writers.

Nevertheless, it is curious that he regards the natural eycle of erosion as destructive rather than one which balances construction with destruction. He seems also to regard man as everywhere destructive, failing to appreciate those areas where man has built up the soil. He regards the modern Italian as one of the best farmers in the world (p. 22) and rates highly European farming generally; yet he does not seem to draw the obvious deduction that a balanced mixed farming with the integration of crops and grass provides the answer he seeks. It is curious to find the acceptance of $\mathbf{1 5 0}$ million (to be reached in
1960) as the maximum population the United States can support, and sixteen acres of land per head (including three of ploughlend) a minimum to maintain the American standard of living. We see here the still amazing contrast between the points of view of Great Britain and America, with the former having at present 1.2 acres $(0.25$ of ploughland) per head on which it is attempting to maintain its standard. It would be well to read Sir John Russell's presidential address to the British Association (see Nature, September 3, 1949, p. 379) side by side with this book.

Dr. Sears's remedy to secure good farming is to use taxation as both an incentive and a punishment -a soluticn of no little interest at the present time. L. Dudley Stamp

\section{Brochure on Penicillin}

By Dr. S. L. Bhatia. Pp. 171. (Ludhiana : Dr. S. L. Bhatia, Government College, 1949.) 1.8 rupees.

THIS is the second volume of the Indian Science Series, which seeks to give, in language which the non-specialist can understand, basic facts about progress in science and industry. After an introduction which briefly summarizes the chief conditions required for the production of penicillin, the author gives, in simple English words, an account of its discovery and its development during and after the Second World War. A description follows of the methods used for its manufacture on a large scale, and the author then discusses the characteristics of penicillin, its standardization and its pharmacological uses. A chapter on its marketing and storage precedes an appendix which discusses some recent developments. A list of references and an index complete a volume which many, who have no expert knowledge of penicillin, will find useful and interesting to read. The copy received lacks the illustration of penicillin crystals mentioned in the list of illustrations. The author believes that "the responsibility for the development and application of science in a democratic country rests ultimately with its eitizens", and his aim has been to place, at a small cost, the knowledge of penicillin at the disposal of laymen, manufacturers, students and any others whom it may interest. He is to be congratulated on the production of this clear and very readable little book.

\section{Organic Syntheses}

An Annual Publication of Satisfactory Methods for the Preparation of Organic Chemicals. Vol. 28. Pp. vit 121. (New York: John Wiley and Sons, Inc.; London: Chapman and Hall, Ltd., 1948.) 15s, net.

7 HIS welcome annual continues to render valuable service to organic chemists seeking reliable methods for preparing a large variety of substances. The current volume adds thirty-seven preparations to the lengthy list, and there is a cumulative subject index covering Volumes 20-28. This index, taken in conjunction with those in the first and second collective volumes of the series, enables a quick reference to be made to any specific substance for which details have been given. Among interesting substances in the issue under notice are trans-1,2-cyclohexanediol, hexamethylene chlorohydrin, 2-hydroxycinchoninic acid, $p$-nitrophenyl sulphide, and vinyl chloroacetate. As usual, the processes are based in the main upon methods already given in chemical literature, and here adapted and improved by one set of workers and checked independently by others. British organic chemists might well contribute in greater measure to this admirable publication.
J. R. 